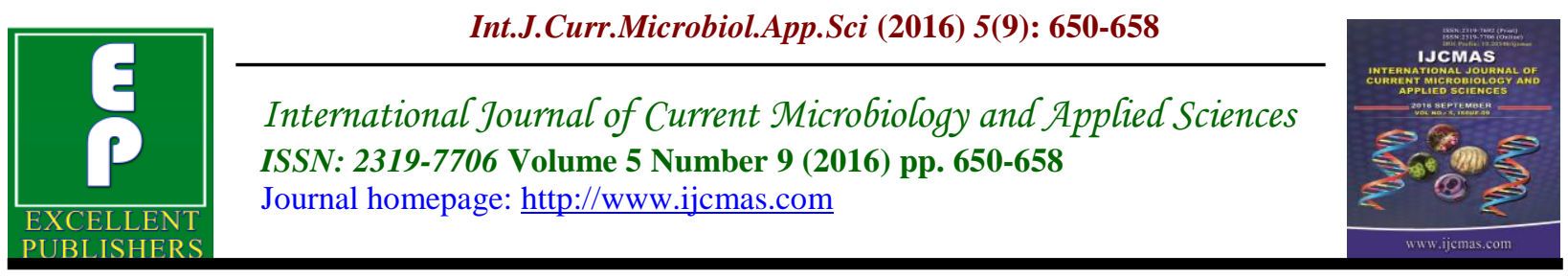

Original Research Article

http://dx.doi.org/10.20546/ijcmas.2016.509.075

\title{
An Essential Role for TGF- $\beta 1$ and other Clinical Parameters in Non-alcoholic Fatty Liver Disease in Iraqi Patients
}

\author{
Huda Jaber Waheed ${ }^{1 *}$, Mostafa Abdulfatah Shafek ${ }^{2}$ and Huda Abdul Ridha Hadi ${ }^{2}$ \\ ${ }^{1}$ University of Al-Mustansiriyah, College of Pharmacy, Clinical Laboratory, \\ Science Department, Iraq \\ ${ }^{2}$ Al-Yarmook Teaching Hospital, Baghdad, Iraq \\ *Corresponding author
}

\begin{abstract}
A B S T R A C T
The aim of this study was to explore the potential role of Transforming growth factor-beta1 (TGF- $\beta 1$ ), tumor necrosis factor-alpha (TNF-alpha) and serum highsensitivity C-reactive protein (hs-CRP) in the Non-alcoholic fatty liver disease (NAFLD). A total of (30) patients with Non-alcoholic fatty liver disease (NAFLD)

Keywords

NAFLD,

TGF- $\beta 1$,

TNF-alpha,

hs-CRP.

Article Info

Accepted:

25 August 2016

Available Online:

10 September 2016 were included in this study. All patients received the concentrations of serum TGF$\beta 1, \mathrm{TNF}-a$ lpha and hs-CRP were measured, and compared with (20) healthy subject as control group. Serum TGF-- $\beta 1$ concentration in patients with NAFLD $(4.33 \pm 0.36 \mathrm{ng} / \mathrm{ml})$ was significantly higher than healthy controls $(2.83 \pm 0.18$ $\mathrm{ng} / \mathrm{ml}),[\mathrm{P}<0.05]$, as well as, TNF-alpha levels in patients were $(42.76 \pm 2.54 \mathrm{pg} / \mathrm{ml})$ which significantly higher $[\mathrm{P}<0.05]$ than the control group $(42.76 \pm 2.54 \mathrm{pg} / \mathrm{ml})$. Serum hs-CRP levels in patients were $(4.51 \pm 0.87 \mathrm{mg} / \mathrm{L})$ and in control group $(2.12 \pm 0.19 \mathrm{mg} / \mathrm{L})$. The area under ROC curve, hs_CRP $\sim$ TNF- $\alpha=0.0656$, hs CRP $\sim$ TGF- $\beta 1=0.273$; TGF- $\beta 1 \sim$ TNF- $\alpha=0.4561)$. TGF- $\beta 1$ was the more sensitive than TNF- $\alpha$ and hs-CRP $(73.3 \%, 63.3 \%$ and $60.0 \%$, respectively). Serum TGF- $\beta 1$, TNF-alpha and hs-CRP significantly elevated in patients with NAFLD. TGF- $\beta 1$ was more sensitive than the other two studied parameters.Serum TGF- $\beta 1$, TNFalpha and hs-CRP may be used as a markers for monitor the development of NAFLD and can reflect the severitv of liver damage.
\end{abstract}

\section{Introduction}

Non-alcoholic fatty liver disease (NAFLD) is one of the most common liver diseases in the world. NAFLD compass a wide spectrum of pathological changes extend from simple steatosis to steatohepatitis, fibrosis and eventually cirrhosis; only a minority of cases develop to end-stages of disease, and the course of the disease development to the late stages tends to be slow, take several years to reach the end stage of disease (Giridhar et al., 2013). Liver cirrhosis is a state in which the liver slowly destroy and lose its functions because of chronic injury. Fatty liver is one of the major conditions of liver fibrosis finally developed to cirrhosis. Transforming growth factor-beta1 (TGF- $\beta 1$ ), one of the three isoforms of TGF- $\beta$, is a cytokine that adjust 
the generation and differentiation of cells, embryonic evolution, wound cure and angiogenesis. (Abeer et al., 2014). Alteration in the production of TGF- $\beta$ related to numerous disease, consist of atherosclerosisor kidney, liver and lung fibrous diseases. In liver diseases, the chronic inflammation, as notes in chronic viral hepatitis, has important role in measuring the deviation in the TGF- $\beta$ signaling track from tumor suppression to fibrogenesis hasten liver fibrosis and increasing the peril of cirrhosis (Matsuzaki et al., 2007).TGF- $\beta$ has three isoform, one of them is TGF- $\beta 1$ that detention the cell cycle in the G1-phase, by blocking cell division and apoptosis (Dong et al., 2008). TGF- $\beta 1$ is a major regulator in chronic liver disease participating to all stages of disease development from incipient liver injury during inflammation to fibrosis and cirrhosis. The function of TGF- $\beta 1$ in the development of liver fibrosis has been widely investigated. TGF- $\beta 1$ favors the conversion of hepatic stellate cells to myofibroblast cells, by stimulation the production of extracellular matrix proteins and block their degradation (Bissell, 2001).

Tumor necrosis factor (TNF-alpha)is a cell signaling protein contributed in systemic inflammation and is a cytokines that substitute the acute phase reaction. TNF- $\alpha$ is generated chiefly by activated macrophages (Swardfager et al., 2010). TNF- $\alpha$ play a major role in the development of liver malfunction in NAFLD (Della et al., 2011).

C-reactive protein is produced by the liverin response to operators released by macrophages and adipocyte. CRP is one of the pentraxin class of proteins. Its level increase in response to inflammation (Pepys et al., 2003). NAFLD related to the risk for components of metabolic syndrome and the connection was stronger in over-weight individuals, especially in female. Insulin resistance and systemic inflammatory response (increase in CRP) are of a major importance for stimulate fatty change in liver lead to NAFLD (Hamed et al., 2015).

Current study aimed to evaluate the role of serum TGF- $\beta 1$, TNF- $\alpha$ and hs-CRP in the development of the Non-alcoholic fatty liver disease (NAFLD).

\section{Patients and Methods}

A total of (30) patients with Non-alcoholic fatty liver disease (NAFLD) were enrolled in the current study, which attending AlKadhumiya Teaching Hospital, Baghdad. All patients were subjected to full history taking, complete clinical examination, abdominal ultrasound, while laboratory investigations were done to all subjects. Patients with hepatitis and alcoholic liver diseases were excluded. For comparison, about (20) healthy subjects was taken in this study.

Serum TGF- $\beta 1$, TNF- $\alpha$ and hs-CRP were measured by enzyme linked immunosorbent assay. Both serum TGF- $\beta 1$ and TNF$\alpha$ were supplied by Ray Biotech, USA, while hs-CRP was supplied by Demeditec Diagnostics GmbH., Germany.

\section{Statistical analysis}

Statistical analysis was using SPSS-21 (Statistical Packages for Social Sciencesversion 21) and Microsoft Office Excel (Microsoft Office Excel for windows; 2010). Unpaired t-test was used to assess significant difference between the means of control and patients. $\mathrm{P}<0.05$ was considered statistically significant.

\section{Results and Discussion}

The mean of serum hs-CRP levels in patients group was $(4.51 \pm 0.87 \mathrm{mg} / \mathrm{L})$ and in 
control $(2.12 \pm 0.19 \mathrm{mg} / \mathrm{L})$ and there was a significant difference $(p>0.05)$ between the two groups when compared to control. Serum TGF- $\beta 1$ levels also shown a significant increase $(\mathrm{p}<0.05)$ in patients group $(4.33 \pm 0.36 \mathrm{ng} / \mathrm{ml})$ when compared to healthy subjects $(2.83 \pm 0.18 \mathrm{ng} / \mathrm{ml})$.The mean of TNF- $\alpha$ levels for patients significantly increase when compared to healthy control group $(42.76 \pm 2.54$ vs. $28.50 \pm 1.28 \mathrm{pg} / \mathrm{ml}$, respectively), as shown in table (1).

In the present study, both age and BMI were matching for patients and control groups and there was no significant difference between them ( $p>0.05)$, table (1). Figure (1) shows the percentage of males and females in the present study, where patients were highest among males (\%32) when compared to female $(28 \%)$, as well as, for healthy subjects the percentage of male $(24 \%)$ was higher than female (16\%).

There was a significant positive correlation between hs-CRP and BMI $(r=0.75$, $\mathrm{p}<0.0001)$, also a significant positive correlation was observed between hs-CRP and TGF-- $\beta 1(\mathrm{r}=0.49, \mathrm{p}<0.05)$, table $(2)$.

Table (2) also shown there was a significant positive correlation between TNF- $\alpha$ and both BMI $(\mathrm{r}=0.71, \mathrm{p}<0.0001)$ and hs-CRP $(r=0.58, p<0.001)$.

Receiver operator curve (ROC) analysis was done and measured the area under curve. Such analysis allow to organize the factors according to the ROC area that can occupy and if such occupation is significant or not. The Pairwise comparison of ROC curves revealed the descending order (hs_CRP TNF- $\alpha=0.0656$, hs_CRP $\sim$ TGF- $\beta 1=0.2730$, TGF- $\beta 1 \sim$ TNF- $\alpha=0.4561$ )

The sensitivity of TGF- $\beta 1$ in NAFLD patients was (73.3\%) and specificity (75\%), as find in ROC analysis, Figure (3).

Serum TNF- $\alpha$ show sensitively (63.3\%) and specificity (95\%), as shown in figure (4).

The sensitivity and specificity for hs-CRP (60\% and $80 \%$, respectively), as shown in figure (6).

The current study was designed to assessed serum TGF- $\beta 1$, TNF- $\alpha$ and hs-CRP for (NAFLD) patients in development of liver cirrhosis.

Serum TGF- $\beta 1$ significantly increase in (NAFLD) patients when compared to control group. These results were in agreement with (Okumoto et al., 2004)who found that plasma TGF- $\beta 1$ concentrations in fatty liver patients with cirrhosis were significantly rise when compare to healthy subjects. His designing study aimed to blocking TGF- $\beta 1$ synthesis and found that the signaling pathways significantly reduced the fibrosis in experimental models (Bataller et al., 2005). As a result, tissue and serum TGF- $\beta 1$ levels are rise in fibrosis and overexpression of TGF- $\beta 1$ in mice model and application of exogenous TGF- $\beta 1$ can stimulate organ fibrosis (Kopp et al., 1996). Adel et al., 2012 reported that liver cell injury due to chronic inflammation, oxidative stress indications, apoptotic bodies, paracrine inducing from hepatocytes lead to initiation of stimulation the HSC (Kupffer cells and sinusoidal endothelial cells) by fast modifications in gene expression and cell phenotype with following recruitment of inflammatory cells, raise the rate of synthesis and releasing of TGF- $\beta$ following by fibro genic actions by very complex pathophysiological pathways (Adel et al., 2012). The range of serum TGF- $\beta 1$ has some limitations due to the contamination of the sample by TGF- $\beta$ from platelets, the intervention with plasmin activity in the plasma that elevated the level 
of TGF- $\beta 1$ by inauguration LAP-TGF- $\beta$ complex, the binding of TGF- $\beta$ at the position of damage to ECM and to vascular endothelium, the confinement by soluble proteins and the difficultly removing the TGF- $\beta 1$. (Zhang et al., 2003). In the current study, TGF- $\beta 1$ positively correlated with BMI, a previous study examined the impact of obesity on the production of TGF- $\beta 1$ by adipocytes. The tumor necrosis factor alpha (TNF-alpha) and/or interleukin 1 beta (IL-1 beta) controlled the production of TGF- $\beta 1$ was examine by explants the adipose tissue with a soluble receptor of TNF-alpha and adding the anti-human IL-1 beta antibody. The production of TGF-beta1 after 48 hours by adipose tissue explants was significantly induced in the presence of TNF- $\alpha$ inhibitor and of IL-1 $\beta$ (Fain, 2005). The present study reported that serumTNF- $\alpha$ levels were significant increase in patients with NAFLD when compared to healthy control subjects. TNF- $\alpha$ has a a wide range of biological function, it is the a major factor in causing liver injury (Guowang et al., 2011). The level of TNF- $\alpha$ was indicating the capability of resisting viral infection, as well as associated with the immuno- pathological to liver damege (Jouxeph, 2016). Previous study suggested that alteration in TNF- $\alpha$ level may be the index of the prognostic evaluation, and TNF- $\alpha$ indecated the inflammation acuity. Hepatic necrosis was indicate by increase TNF-alpha level, it might be one of the most important causes of death (Guowang et al., 2011).

Table.1 The clinical characteristics for patients and control groups.

\begin{tabular}{|c|c|c|c|c|c|c|}
\hline Group & & $\begin{array}{l}\text { Age } \\
\text { (Year) }\end{array}$ & $\begin{array}{l}\text { BMI } \\
\left(\mathrm{Kg} / \mathrm{m}^{2}\right)\end{array}$ & $\begin{array}{l}\text { hs-CRP } \\
(\mathrm{mg} / \mathrm{L})\end{array}$ & $\begin{array}{l}\text { TGF- } \beta 1 \\
(\mathrm{ng} / \mathrm{ml})\end{array}$ & $\begin{array}{l}\text { TNF- } \alpha \\
(p g / m l)\end{array}$ \\
\hline \multirow[t]{2}{*}{ Control } & Mean \pm SD & $55.90 \pm 1.17$ & $30.08 \pm 0.80$ & $2.12 \pm 0.19$ & $2.83 \pm 0.18$ & $28.50 \pm 1.28$ \\
\hline & Range & $47.0-67.0$ & $24.6-34.9$ & $0.32-3.89$ & $0.9-4.2$ & $20.0-39.0$ \\
\hline \multirow[t]{3}{*}{ Patients } & Mean \pm SD & $57.70 \pm 0.96$ & $30.07 \pm 0.69$ & $4.51 \pm 0.87$ & $4.33 \pm 0.36$ & $42.76 \pm 2.54$ \\
\hline & Range & $50.0-67.0$ & $24.2-37.3$ & $0.05-17.9$ & $1.2-8.8$ & $21.0-70.0$ \\
\hline & P value & 0.23 & 0.92 & 0.02 & 0.002 & $<0.0001$ \\
\hline
\end{tabular}

Table.2 The correlations between studied parameters in patients group.

\begin{tabular}{|l|l|l|l|l|l|}
\hline \multirow{2}{*}{ Age } & & BMI & hs-CRP & TGF-- 11 & TNF- $\alpha$ \\
\hline BMI & $\mathbf{r}$ & 0.07 & -0.06 & -0.13 & 0.29 \\
\hline & $\mathbf{p}$ & 0.71 & 0.72 & 0.48 & 0.11 \\
\hline hs-CRP & $\mathbf{r}$ & & 0.75 & 0.38 & 0.71 \\
\hline & $\mathbf{p}$ & & $<0.0001$ & 0.03 & $<0.0001$ \\
\hline TGF- $\beta 1$ & $\mathbf{p}$ & & & 0.49 & 0.58 \\
\hline & $\mathbf{p}$ & & & 0.005 & 0.0007 \\
\hline & $\mathbf{p}$ & & & & 0.29 \\
\hline & & & & & 0.11 \\
\hline
\end{tabular}


Table.3 Pairwise comparison of ROC curves

\begin{tabular}{|c|c|}
\hline \multicolumn{2}{|l|}{ hs_CRP TGF } \\
\hline Difference between areas & 0.0983 \\
\hline Standard Error ${ }^{\mathrm{a}}$ & 0.0897 \\
\hline 95\% Confidence Interval & -0.0775 to 0.274 \\
\hline z statistic & 1.096 \\
\hline Significance level & $\mathrm{P}=0.2730$ \\
\hline \multicolumn{2}{|l|}{ hs_CRP TNF } \\
\hline Difference between areas & 0.159 \\
\hline Standard Error ${ }^{\mathrm{a}}$ & 0.0864 \\
\hline 95\% Confidence Interval & -0.0103 to 0.329 \\
\hline z statistic & 1.841 \\
\hline Significance level & $P=0.0656$ \\
\hline \multicolumn{2}{|l|}{$\mathrm{TGF} \sim \mathrm{TNF}$} \\
\hline Difference between areas & 0.0608 \\
\hline Standard Error ${ }^{\mathrm{a}}$ & 0.0816 \\
\hline 95\% Confidence Interval & -0.0991 to 0.221 \\
\hline z statistic & 0.745 \\
\hline Significance level & $P=0.4561$ \\
\hline
\end{tabular}

Fig.1 Male to female ratio among the studied groups

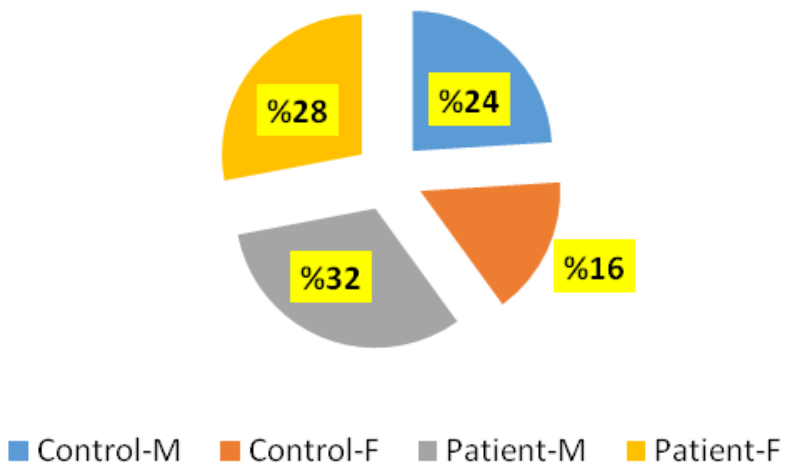


Fig.2 Receiver operator curve (ROC) analysis for the investigated parameters in patients and controls.

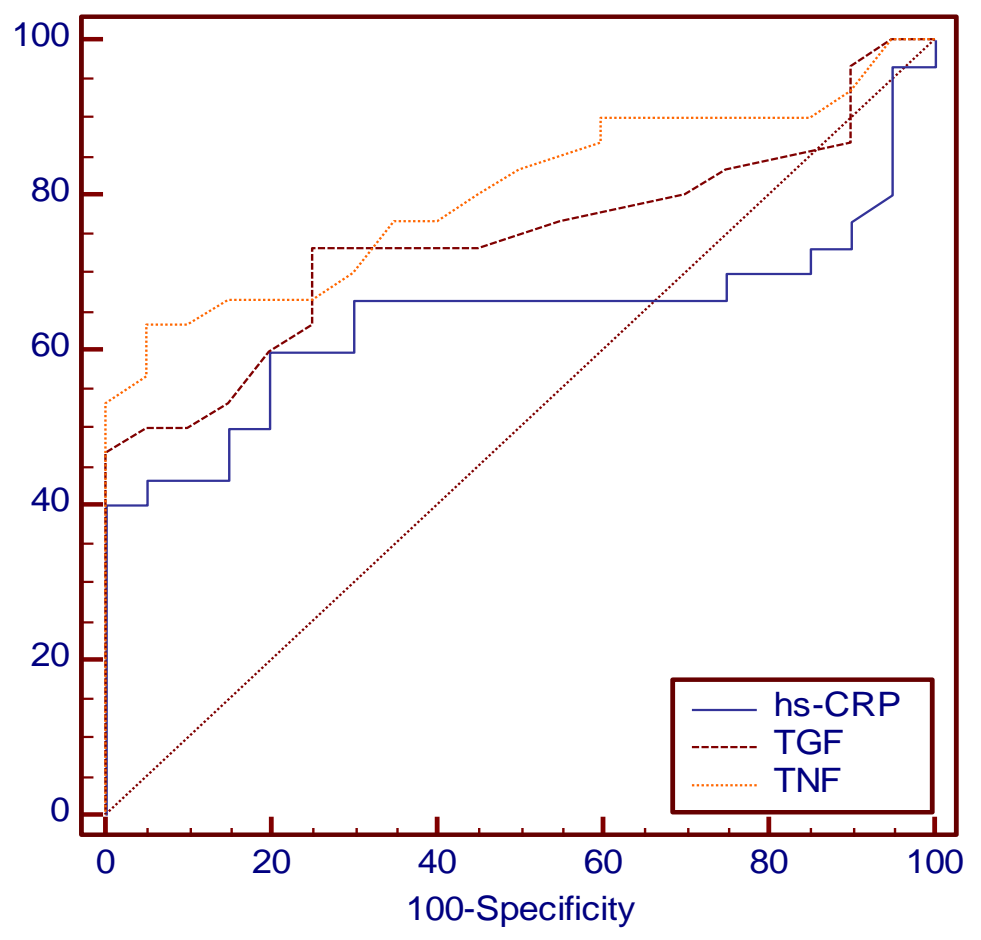

Fig.3 Receiver operator curve (ROC) analysis for TGF- $\beta 1$.

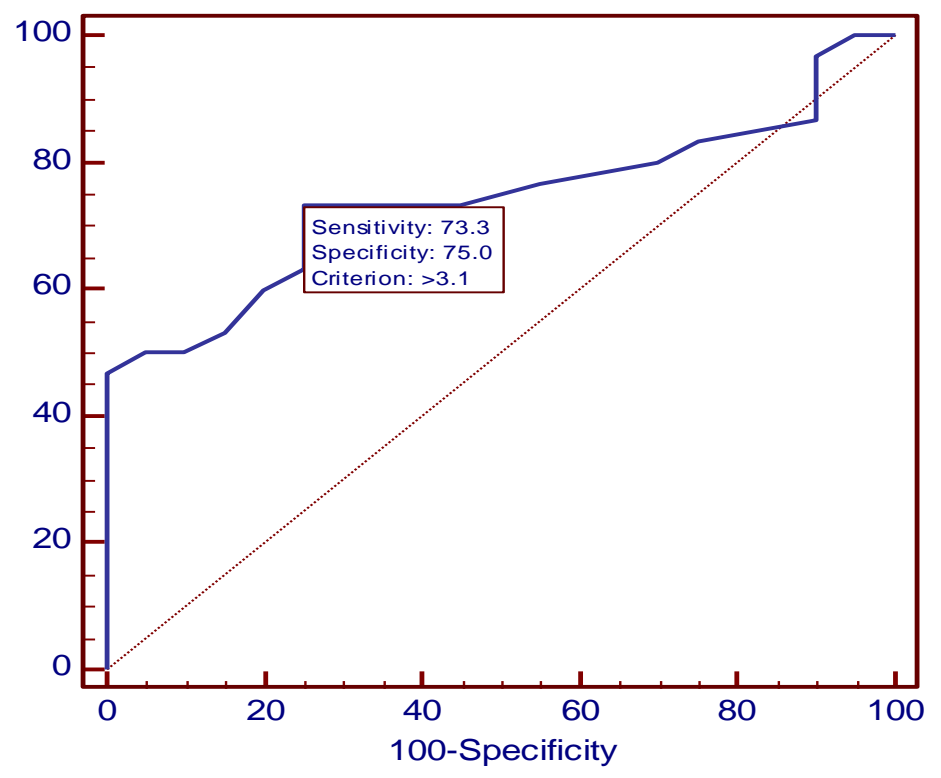


Fig.4 Receiver operator curve (ROC) analysis for TNF- $\alpha$.

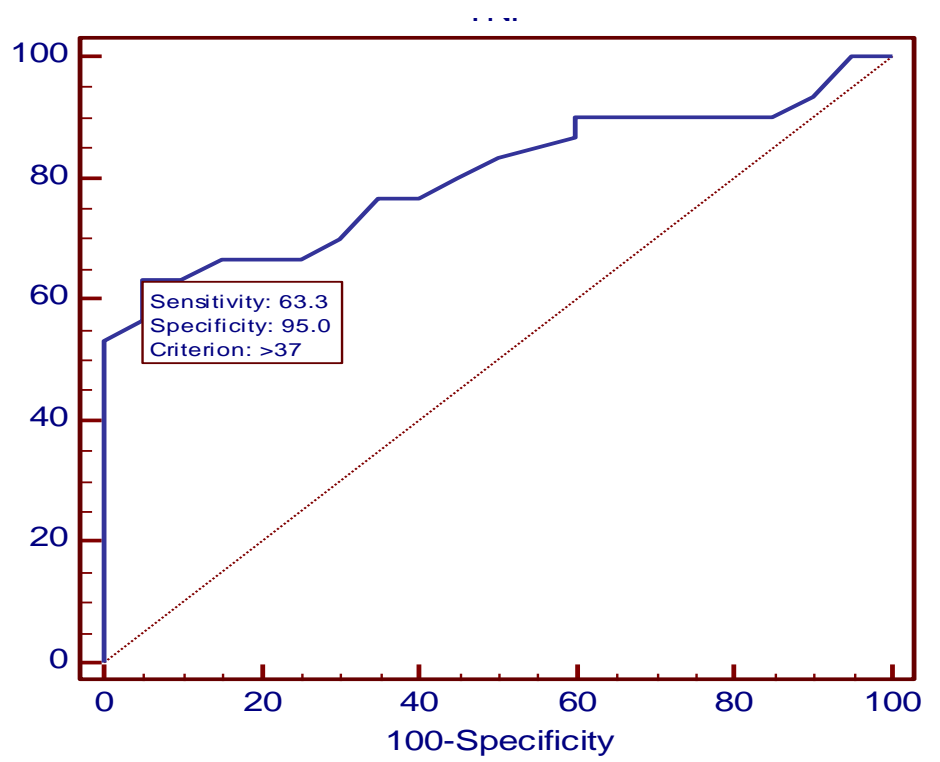

Fig.5 Receiver operator curve (ROC) analysis for hs-CRP.

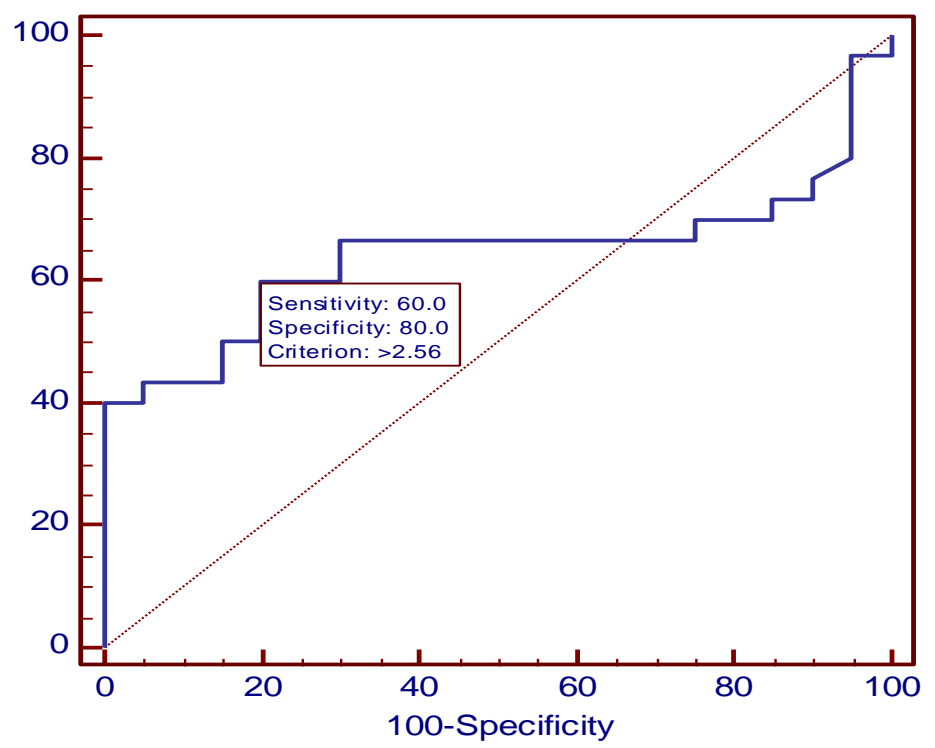

Serum hs-CRP levels in patients group was significantly higher than in control group. Recent study found that liver steatosis leads to elevated hs-CRP levels, independent of BMI, lobular inflammation, hepatocyte ballooning and fibrosis. It thus appeared that it is the increased of adipocytes as liver steatosis -might lead to elevated hs-CRP levels in over-weight patients. C-reactive protein can be act as a marker of steatosis, but not in other liver disease cases (Esther et al., 2015).

There was a significant correlation between hs-CRP and BMI. Recent study record that BMI is a good predictor of elevate hs-CRP in obese patients. This may be due to the inflammatory proteins which released from 
the adipose tissue. The adipose tissue can enhanced the chronic low-grade inflammation by released inflammatory cytokines (Yeniova et al., 2014). The increment in the CRP expression has been revealed in severe obesity. This suggests that the adipose tissue is also a source of hsCRP production. The CRP expression in the liver more than in the adipose tissue. The total amount of hs-CRP released in the adipose tissue may be limited by the amount of adipose tissue of the human body (Esther et al., 2015).

In conclusion, transforming growth factorbeta1 (TGF- $\beta 1$ ), tumor necrosis factor-alpha (TNF-alpha) and serum high-sensitivity Creactive protein (hs-CRP) significantly elevated in patients with NAFLD. TGF- $\beta 1$ was more sensitive than the other two studied parameters. It emerged that the obesity effect on the studied parameters and thus influence the progression of the disease.

\section{References}

Abeer Mohy, Ahmed Fouad. 2014. Role of transforming growth factor- $\beta 1$ in serum and $-509 \mathrm{C}>\mathrm{T}$ promoter gene polymorphism in development of liver cirrhosis in Egyptian patients. Meta Gene, Volume 2, pp 631-637.

Adel, A., Mahmoud, Amal, S., Bakir and Sherif, S., Shabana. 2012. Serum TGF$\beta$, Serum MMP-1, and HOMA-IR as Non-Invasive Predictors of Fibrosis in Egyptian Patients with NAFLD. Saudi J. Gastroenterol., 18(5): pp 327-333

Bissell, D.M. 2001. Chronic liver injury, TGF- $\beta$, and cancer. Exp. Mol. Med., 33, pp. 179-190.

Della Corte, C., Alisi, A., Iorio, R. et al. 2011. Expert opinion on current therapies for nonalcoholic fatty liver disease. Expert Opin. Pharmachother., 12, pp1901-1911.
Dong, D.F., Yao, M., Tao, L.W., Qiu, L., Zong, W., Wu, X.H., Wu, D.B., Yao, X.Y., Meng. 2008. Clinical impact of plasma TGF- $\beta 1$ and circulating TGF$\beta 1$ mRNA in diagnosis of hepatocellular carcinoma. Hepatobiliary Pancreat Dis. Int., 7(3), pp. 288-295.

Esther Zimmermann, Rodolphe Anty, Joan Tordjman. et al. 2015. C-reactive protein levels in relation to various features of non-alcoholic fatty liver disease among obese patients. $J$. Hepatol., 11(6): pp1122-27.

Fain, J.N., Tichansky, D.S., Madan, A.K. 2005. Transforming growth factor beta1 release by human adipose tissue is enhanced in obesity. Metabolism, 54(11), pp1546-51.

Giridhar Kanuri, Ina Bergheim. 2013. In Vitro and in Vivo Models of NonAlcoholic Fatty Liver Disease (NAFLD). Int. J. Mol. Sci., 14, pp 11963-11980.

Guowang Liu, Kecheng Tang, Qian Li, Guiyu Yuan, Wukui Cao, Wei Lu. 2011. Changes of IL-1, TNF-Alpha, IL-12 and IL-10 Levels with Chronic Liver Failure. Surgical Sci., 2(11), pp 69-72.

Hamed, A.E., Abas, B., Shaltout, I., Esmt, G., Gomez, R., et al. 2015. Managing Diabetes and Liver Disease Association, Guidelines (Consensus) Development. J. Endocrinol. Diab. Obes., 3(3): pp 1073-78.

Kopp, J.B., V.M. Factor, M. Mozes, P. Nagy, N. Sanderson, E.P. Bottinger. 1996. Transgenic mice with increased plasma levels of TGF- $\beta 1$ develop progressive renal disease. Lab. Invest., 74, pp. 991-1003.

Jouxeph, M.D. 2016. "Diagnostic, Pathlolgy and treatment for liver disease, J. Clin Hepatol., 3(6): pp 21318. 
Matsuzaki, K., M. Murata, K. Yoshida, G. Sekimoto, Y. Uemura, N. Sakaida. 2007. Chronic inflammation associated with hepatitis $\mathrm{C}$ virus infection perturbs hepatic transforming growth factor beta signaling, promoting cirrhosis and hepatocellular carcinoma Hepatol., 46, pp. 48-57.

Okumoto, K., E. Hattori, K. Tamura, S. Kiso, H. Watanabe, K. Saito. 2004. Possible contribution of circulating transforming growth factor-betal to immunity and prognosis of unresectable hepatocellular carcinoma. Liver Int., 24, pp. 21-28.

Pepys, M.B., Hirschfield, G.M. 2003. "Creactive protein: a critical update". $J$. Clin. Investigation, 111(12): 1805-12.

Bataller, R., D.A. Brenner. 2005. Liver fibrosis. J. Clin. Invest., 115, pp. 209218.

Swardfager, W., Lanctôt, K., Rothenburg, L., Wong, A., Cappell, J., Herrmann,
N. 2010. "A meta-analysis of cytokines in Alzheimer's disease". Biol. Psychiatry, 68(10), pp930-941.

Yeniova, A.O., Küçükazman, M., Ata, N, Dal, K., Kefeli, A., Başyiğit, S., Aktaş, B., Ağladioğlu, K., Akin, K.O. Ertugrul, D.T., Nazligül, Y., Beyan, E. 2014. High-sensitivity C-reactive protein is a strong predictor of nonalcoholic fatty liver disease. Hepatogastroenterol., 61(130): pp4225.

Zhang, B.B., Min Cai, W., Weng, H.L., Hu, Z.R., Lu, J., Zheng, M., et al. 2003. Diagnostic value of platelet derived growth factor-BB, transforming growth factor-b1, matrix metalloproteinase-1 in serum and peripheral blood mononuclear cells for hepatic fibrosis. World $J$. Gastroenterol., 9(6): pp 2490-6.

\section{How to cite this article:}

Huda Jaber Waheed, Mostafa Abdulfatah Shafek and Huda Abdul Ridha Hadi. 2016. An Essential Role for TGF- $\beta 1$ and other Clinical Parameters in Non-alcoholic Fatty Liver Disease in Iraqi Patients. Int.J.Curr.Microbiol.App.Sci. 5(9): 650-658. doi: http://dx.doi.org/10.20546/ijcmas.2016.509.075 